WSRC-TR-2004-00316

Revision 1

\title{
ANALYTICAL RESULTS OF DWPF GLASS SAMPLE TAKEN DURING FILLING OF CANISTER S01913
}

\author{
A.D. Cozzi \\ N.E. Bibler
}

September 2004

Immobilization Technology Section

Savannah River National Laboratory

Savannah River National Laboratory

Aiken, SC 29808

Prepared for the U.S. Department of Energy Under Contract Number DEAC09-96SR18500 
This document was prepared in conjunction with work accomplished under Contract No. DE-AC09-96SR18500 with the U. S. Department of Energy.

\section{DISCLAIMER}

This report was prepared as an account of work sponsored by an agency of the United States Government. Neither the United States Government nor any agency thereof, nor any of their employees, makes any warranty, express or implied, or assumes any legal liability or responsibility for the accuracy, completeness, or usefulness of any information, apparatus, product or process disclosed, or represents that its use would not infringe privately owned rights. Reference herein to any specific commercial product, process or service by trade name, trademark, manufacturer, or otherwise does not necessarily constitute or imply its endorsement, recommendation, or favoring by the United States Government or any agency thereof. The views and opinions of authors expressed herein do not necessarily state or reflect those of the United States Government or any agency thereof.

This report has been reproduced directly from the best available copy.

Available for sale to the public, in paper, from: U.S. Department of Commerce, National Technical Information Service, 5285 Port Royal Road, Springfield, VA 22161, phone: (800) 553-6847, fax: (703) 605-6900

email: orders@ntis.fedworld.gov

online ordering: http://www.ntis.gov/help/index.asp

Available electronically at http://www.osti.gov/bridge

Available for a processing fee to U.S. Department of Energy and its contractors, in paper, from: U.S. Department of Energy, Office of Scientific and Technical Information, P.O. Box 62, Oak Ridge, TN 37831-0062,

phone: (865)576-8401,

fax: (865)576-5728

email: $\underline{\text { reports@ adonis.osti.gov }}$ 
WSRC-TR-2004-00316

Revision 1

Key Words: $D W P F$

Macrobatch 3

Sludge Batch 2

Glass

Retention: Permanent

\title{
ANALYTICAL RESULTS OF DWPF GLASS SAMPLE TAKEN DURING POURING OF CANISTER S01913
}

\author{
A.D. Cozzi \\ N.E. Bibler
}

September 2004

Immobilization Technology Section

Savannah River National Laboratory

Savannah River National Laboratory

Aiken, SC 29808

Prepared for the U.S. Department of Energy Under Contract Number DEAC09-96SR18500

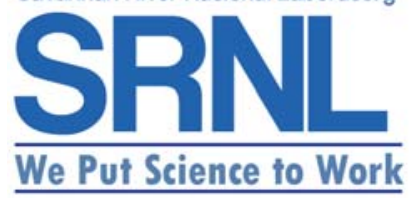


This page was intentionally left blank 


\section{REVISIONS}

\begin{tabular}{|c|c|c|c|}
\hline $\begin{array}{l}\text { Revision } \\
\text { Number: }\end{array}$ & $\begin{array}{l}\text { Page } \\
\text { Number: }\end{array}$ & Date: & Revision: \\
\hline 0 & All & $8 / 10 / 04$ & Original Issue \\
\hline \multirow[t]{4}{*}{1} & 7 & $9 / 13 / 04$ & $\begin{array}{l}\text { Table } 3-5 \text {. Source of Am- } 243 \text { value was changed from } \\
\text { Reference } 8 \text { to ICP-MS. }\end{array}$ \\
\hline & 8 & $9 / 13 / 04$ & $\begin{array}{l}\text { Table 3-6. Values in "Wt \% Glass (Measured)" and } \\
\text { "Ci/Kg/ Glass" columns were updated to reflect new } \\
\text { analysis of the ICP-MS spectra for U-233, U-234, U- } \\
235, \mathrm{U}-236, \mathrm{~Np}-237, \mathrm{U}-238, \mathrm{Pu}-238, \mathrm{Pu}-239, \mathrm{Pu}-240 \text {, } \\
\mathrm{Pu}-242 \text {, and Am-243. Significant differences were } \\
\text { noted in the Pu-239 and Pu-242 values. }\end{array}$ \\
\hline & & & $\begin{array}{l}\text { The original results were calculated from the Integrated } \\
\text { Counts Per Second data set generated by the ICP-MS } \\
\text { PlasmaLab Software. Comparison of the data with } \\
\text { expected results suggested an anomaly in the higher } \\
\text { mass isotope concentrations. ADS analysis of } \\
\text { information available from the instrument run on these } \\
\text { samples confirmed the finding and reissued corrected } \\
\text { results. }\end{array}$ \\
\hline & & & $\begin{array}{l}\text { ADS personnel issued a memo, SRNL-ADS-2004- } \\
00158 \text {, to describe the issue and resolution of the } \\
\text { anomaly. }\end{array}$ \\
\hline
\end{tabular}


WSRC-TR-2004-00316

Revision 1

This page intentionally left blank. 


\section{EXECUTIVE SUMMARY}

- The Defense Waste Processing Facility (DWPF) began processing Sludge Batch 2 (SB2) (Macrobatch 3) in December 2001 as part of Sludge Receipt and Adjustment Tank (SRAT) Batch 208. Macrobatch 3 consists of the contents of Tank 40 and Tank 8 in approximately equal proportions. A glass sample was obtained while pouring Canister S01913 and was sent to the Savannah River National Laboratory (SRNL) Shielded Cells for characterization. This report contains observations of the glass sample, results for the density, the chemical composition, the Product Consistency Test (PCT) and the radionuclide results needed for the Production Record for Canister S01913.

- The as-received glass appeared homogeneous over the entire surface with a dark and reflective luster. The glass sample weighed 33.04 grams. The results of the composition for glass sample S01913 are in good agreement with the DWPF Slurry Mix Evaporator (SME) results for Batch Number 254, the SME Batch that was being fed to the melter when the sample was collected. The PCT results for the glass indicate that it is significantly more durable than the Environmental Assessment (EA) glass with a normalized boron release of $1.18 \mathrm{~g} / \mathrm{L}$ for the glass and $10.5 \mathrm{~g} / \mathrm{L}$ measured for the EA glass. Thus, the glass meets the waste acceptance criterion for durability. The measured density of the glass was $2.56 \pm 0.03$ $\mathrm{g} / \mathrm{cm}^{3}$. 


\section{TABLE OF CONTENTS}

REVISIONS

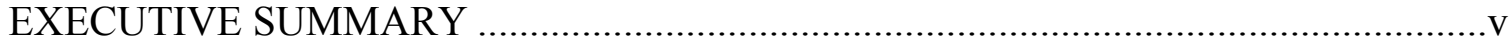

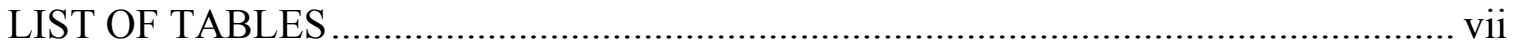

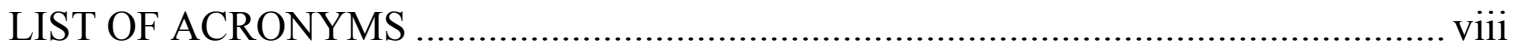

1.0 INTRODUCTION AND BACKGROUND .......................................................

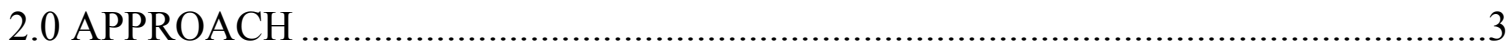

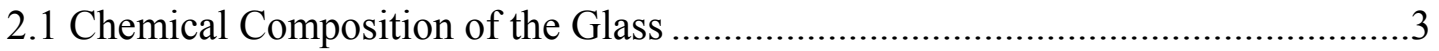

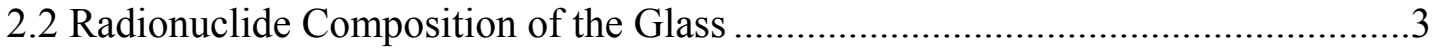

2.3 Noble Metal Composition of the Glass ........................................................ 3

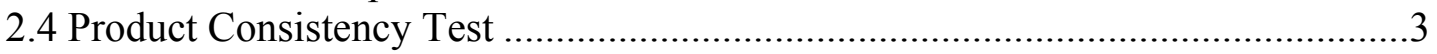

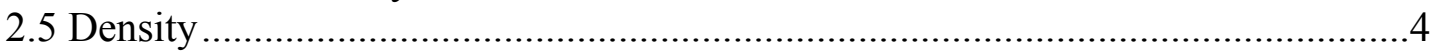

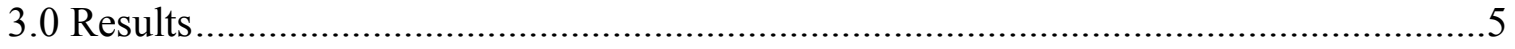

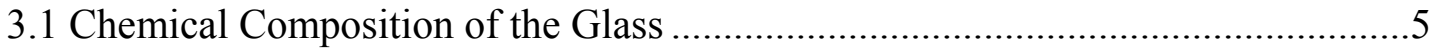

3.2 Radionuclide Composition of the Glass ......................................................

3.3 Noble Metal Composition of the Glass ......................................................

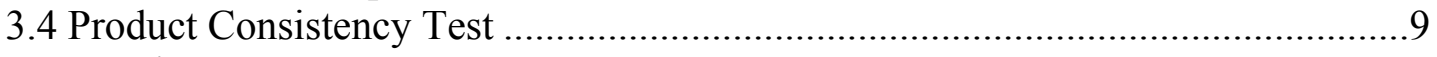

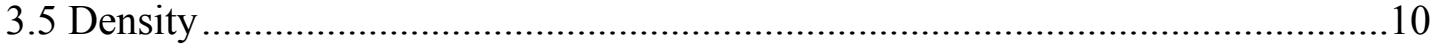

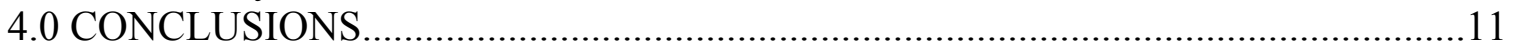

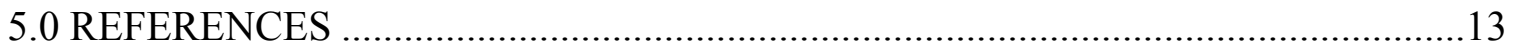




\section{LIST OF TABLES}

Table 3-1. Published and Average Measured Values of Analytical Reference Glass-1......5

Table 3-2. Oxide Composition of Glass Pour Stream Sample Taken during Filling of Canister S01913.

Table 3-3. Concentration of Major ( $>0.5$ Wt. \% Elemental) Components of Glass Pour Stream Sample Taken during Filling of Canister S01913.

Table 3-4. Concentrations of Elements in the Dried Sludge Slurry, the Glass Pour
Stream Sample, and the Calculated WDF....................................................

Table 3-4. Concentrations of Elements in the Dried Sludge Slurry, the Glass Pour
Stream Sample, and the Calculated WDF...................................................

Table 3-5. Reportable Radionuclides for Macrobatch 3 Identified in Reference 7............7

Table 3-6. Radionuclide Content of the Glass Pour Stream Sample Taken during the Filling of Canister S01913.

Table 3-7. Measured Noble Metal Concentration in Glass Pour Stream Sample Taken during the Filling of Canister S01913.

Table 3-8. Normalized PCT Results (Measured and Predicted) for Glass Pour Stream Sample Taken during the Filling of Canister S01913.

Table 3-9. Density of the Glass Pour Stream Sample Taken during the Filling of Canister S01913. 


\section{LIST OF ACRONYMS}

$\begin{array}{ll}\text { ADS } & \text { Analytical Development Section } \\ \text { AES } & \text { Atomic Emission Spectroscopy } \\ \text { ARG-1 } & \text { Analytical Reference Glass 1 } \\ \text { ARM-1 } & \text { Approved Reference Material-1 } \\ \text { CPC } & \text { Chemical Processing Cell } \\ \text { DWPF } & \text { Defense Waste Processing Facility } \\ \text { EA } & \text { Environmental Assessment } \\ \text { ICP } & \text { Inductively Coupled Plasma } \\ \text { MB3 } & \text { Macrobatch 3 } \\ \text { MFT } & \text { Melter Feed Tank } \\ \text { MS } & \text { Mass Spectroscopy } \\ \text { PCT } & \text { Product Consistency Test } \\ \text { SME } & \text { Slurry Mix Evaporator } \\ \text { SRAT } & \text { Sludge Receipt and Adjustment Tank } \\ \text { SRNL } & \text { Savannah River National Laboratory } \\ \text { WAPS } & \text { Waste Acceptance Product Specifications } \\ \text { WDF } & \text { Waste Dilution Factor }\end{array}$




\subsection{INTRODUCTION AND BACKGROUND}

The Defense Waste Processing Facility (DWPF) began processing Sludge Batch 2 (SB2) in December 2001 as part of Sludge Receipt and Adjustment Tank (SRAT) Batch 208. Sludge Batch 2 consists of the contents of Tank 40 and Tank 8 in approximately equal proportions.

The sludge slurry is received into the DWPF Chemical Processing Cell (CPC) and is processed through the SRAT and Slurry Mix Evaporator Tank (SME). The treated sludge slurry is then transferred to the Melter Feed Tank (MFT) and fed to the melter. During the processing of each sludge batch, the DWPF is required to take at least one glass sample. This glass sample is taken to meet the objectives of the Glass Product Control Program ${ }^{1}$ and to complete the necessary Production Records so that the final glass product may be disposed of at a Federal Repository.

The DWPF requested analysis of a radioactive glass sample obtained from the melter pour stream during the processing of Macrobatch 3 (MB3) (Sludge Batch 2) ${ }^{2}$ with Frit 320. A glass sample was obtained while pouring Canister S01913 and was sent to the Savannah River National Laboratory (SRNL) Shielded Cells for characterization. Canister S01913 was the 267th canister poured during vitrification of Sludge Batch 2 (364 canisters of glass were prepared from SB2). The glass sample arrived from DWPF in primary container PC0034. The primary container contained pieces of glass. The glass had been extracted from the sample holder in the DWPF. This report contains the visual observations of the as-received glass sample, results for the density, the chemical composition, the Product Consistency Test (PCT) and the calculated and measured radionuclide results needed for the Production Record for Canister S01913, ${ }^{2,4}$. 
WSRC-TR-2004-00316

Revision 1

This page intentionally left blank. 


\subsection{APPROACH}

The glass sample was removed from the primary container, weighed, and visual observations were recorded. A portion of the glass was prepared for the Product Consistency Test (PCT). The glass was ground using a remotely operated, automatic agate mortar and pestle. This method proved too aggressive for preparing the particle size necessary for the PCT and the remainder of glass was prepared using the stainless steel Tekmar grinder. Glass produced by the agate mortar and pestle that was too fine for the PCT (-200 mesh) was dissolved for determining the measured composition of the glass using Inductively Coupled Plasma - Atomic Emission Spectroscopy (ICP-AES) and the radionuclide content of the glass using ICP - Mass Spectroscopy (MS). The remaining fines were used to determine the density using a pycnometer. ICP-AES results for select elements were used to calculate a waste dilution factor (WDF) that is then used to calculate the concentration of radionuclides measured in the sludge slurry but cannot be readily measured in the glass. The specific analyses performed are published in the analytical study plan and relevant information is in laboratory notebook, "DWPF Glass Pour Stream Samples Sludge Batch 2", WSRC-NB-2002-00092.

\subsection{Chemical Composition of the Glass}

The measured elemental composition of the glass was obtained by dissolving a sample of the ground glass and analyzing the resulting solutions using ICP-AES. Dissolution of the glass samples was performed remotely in the Shielded Cells of SRNL. A portion of the glass sample was dissolved in quadruplicate by two separate dissolution methods, a mixed acid dissolution ${ }^{5}$ and a sodium peroxide fusion $^{6}$. The acid dissolution method uses boric acid to complex the fluorine used to help dissolve the glass. Thus, the boron content of the glass cannot be obtained by this method. The sodium peroxide fusion uses sodium peroxide to render the glass more soluble. Thus, the sodium content of the glass cannot be obtained by this method. The peroxide fusions were performed in zirconium crucibles; thus the zirconium content of the glass could not be obtained by the peroxide dissolution method. The samples for the dissolutions were obtained from the glass that was ground and sieved for the PCT. A standard glass with a composition similar to the DWPF glass, Analytical Reference Glass-1 (ARG-1) ${ }^{7}$, was also dissolved and analyzed concurrently with the DWPF glass. The average of the eight replicates (four from each dissolution method) was used unless otherwise noted.

\subsection{Radionuclide Composition of the Glass}

Glass that was dissolved by the acid dissolution method was analyzed using ICP-MS to determine the actinide and fission product content of the glass. Glass dissolved by the peroxide fusion method was analyzed by counting methods to calculate concentrations in the glass. Radionuclide concentrations that are required for the glass product control program ${ }^{1}$ that were not measured in this study are calculated from the sludge slurry results ${ }^{8}$ using a WDF.

\subsection{Noble Metal Composition of the Glass}

Glass that was dissolved by the acid dissolution method was analyzed using ICP-MS to determine the concentration of select noble metals in the glass.

\subsection{Product Consistency Test}

The PCT $^{9}$, a crushed glass leach test using ASTM Type I water, was performed in quadruplicate in Cell 14 using a sample of the glass. The test, which was performed at $90^{\circ} \mathrm{C}$ for seven days, included the appropriate blanks and standards (Environmental Assessment (EA) glass and Approved Reference Material-1 (ARM-1)). 
The concentrations of boron, lithium, sodium and silicon were measured using ICP-AES in the leachate. The concentrations were used along with the measured chemical composition of the glass to calculate the average normalized releases in terms of grams of glass dissolved per liter of leachate based on the specific elements in the glass.

\subsection{Density}

The density of the glass was measured in triplicate using the ASTM procedure ${ }^{10}$ for measuring particle density. A procedure that uses particles was applied to take advantage of the ground glass produced in the automatic mortar and pestle. A portion of the glass was placed into a volumetric flask that has confirmed volume markings. The mass of the glass added was measured and water was added to the mark of known volume. The volume of the glass was then calculated from the mass of the water. Thus the density of the glass was obtained. The procedure was modified for performance in the shielded cells. The glass used was the remaining fines from the grinding of the glass for PCT. 


\subsection{RESULTS}

Analyses to determine the composition, radionuclide content, PCT response and density of the glass obtained during the filling of canister S01913 were measured and calculated using the approach in Section 2.0. The visual observations of the as-received glass were that the glass was dark and reflective with no obvious inclusions or irregularities.

\subsection{Chemical Composition of the Glass}

Table 3-1 shows the measured and published compositions for the ARG-1 glass. Except as noted in the table, the measured values are averages of four replicates from the two dissolution methods. Results indicate that the dissolutions were complete $(95 \leq$ sum of oxides $\leq 105)$ and the analytical procedures were performed correctly (multi-element standards measured within ten percent of the standards values).

Table 3-1. Published and Average Measured Values of Analytical Reference Glass-1.

\begin{tabular}{|c|c|c|c|}
\hline & Measured (wt.\%) & "Published (wt.\%) $^{7}$ ) & Measured/Published \\
\hline $\mathrm{Al}_{2} \mathrm{O}_{3}$ & 4.35 & 4.72 & 0.92 \\
\hline $\mathrm{B}_{2} \mathrm{O}_{3}$ & $7.50^{\mathrm{a}}$ & 8.66 & 0.87 \\
\hline $\mathrm{BaO}$ & 0.09 & 0.09 & 1.05 \\
\hline $\mathrm{CaO}$ & 1.43 & 1.53 & 0.94 \\
\hline $\mathrm{Cr}_{2} \mathrm{O}_{3}$ & 0.10 & 0.09 & 1.08 \\
\hline $\mathrm{Fe}_{2} \mathrm{O}_{3}$ & 13.37 & 14.00 & 0.95 \\
\hline $\mathrm{K}_{2} \mathrm{O}$ & 3.13 & 2.71 & 1.15 \\
\hline $\mathrm{Li}_{2} \mathrm{O}$ & 3.23 & 3.21 & 1.01 \\
\hline $\mathrm{MgO}$ & 0.81 & 0.86 & 0.94 \\
\hline $\mathrm{MnO}_{2}$ & 2.22 & 2.31 & 0.96 \\
\hline $\mathrm{Na}_{2} \mathrm{O}$ & $11.12^{b}$ & 11.48 & 0.97 \\
\hline $\mathrm{NiO}$ & 1.01 & 1.05 & 0.96 \\
\hline$\overline{\mathrm{P}_{2} \mathrm{O}_{5}}$ & 0.33 & 0.25 & 1.30 \\
\hline $\mathrm{SiO}_{2}$ & $47.42^{\mathrm{a}}$ & 47.92 & 0.99 \\
\hline $\mathrm{TiO}_{2}$ & 1.11 & 1.15 & 0.97 \\
\hline $\mathrm{ZnO}$ & 0.03 & 0.02 & 1.27 \\
\hline $\mathrm{ZrO}_{2}$ & $0.13^{b}$ & 0.13 & 1.01 \\
\hline Total & 96.97 & 100.18 & -- \\
\hline
\end{tabular}

${ }^{\mathrm{a}}$ Obtained from analysis of peroxide fusion dissolution.

bobtained from analysis of mixed acid dissolution.

Table 3-2 presents the results for the glass sample taken during the filling of canister S01913. As with the ARG-1 glass, the average of the eight replicates (four from each dissolution method) was used unless otherwise noted. The relative standard deviation of the major components ( $>0.5 \mathrm{wt} \%$ in glass $)$ is less than five percent, indicating good precision of the results. Table 3-3 compares the results for elements that comprise $>0.5 \mathrm{wt} \%$ of the glass with the concentration of these oxides in SME Batch 254, the material in the melter and the materials being fed to the melter at the time the glass sample was taken. The ratio of the concentration of several of the major components in Table 3-3 to their concentration in the sludge as reported in the MB3 Qualification Run ${ }^{11}$ in the SRNL shielded cells is used to calculate the waste dilution factor (WDF) in Table 3-4. The WDF is calculated from aluminum, calcium, iron and manganese ${ }^{12}$. The average WDF calculated from these elements is 2.5. This will be used in Section 3.2 to calculate the concentration of reportable radionuclides (with the exception of C-14 and I-129) that were not measured in the glass. 
WSRC-TR-2004-00316

Revision 1

Table 3-2. Oxide Composition of Glass Pour Stream Sample Taken during Filling of Canister S01913.

\begin{tabular}{|c|c|c|c|}
\hline Oxide & $\mathrm{Wt} \%$ & $\begin{array}{l}\text { Standard } \\
\text { Deviation }\end{array}$ & $\begin{array}{c}\text { Relative } \\
\text { Standard } \\
\text { Deviation }\end{array}$ \\
\hline $\mathrm{Al}_{2} \mathrm{O}_{3}$ & 4.34 & $7.6 \mathrm{E}-02$ & $1.7 \%$ \\
\hline $\mathrm{B}_{2} \mathrm{O}_{3}$ & $4.44^{\mathrm{a}}$ & $4.0 \mathrm{E}-02$ & $0.91 \%$ \\
\hline $\mathrm{BaO}$ & 0.05 & $2 \mathrm{E}-03$ & $5 \%$ \\
\hline $\mathrm{CaO}$ & 1.31 & $3.4 \mathrm{E}-02$ & $2.6 \%$ \\
\hline $\mathrm{CdO}$ & 0.05 & 2E-03 & $3 \%$ \\
\hline $\mathrm{CeO}_{2}$ & 0.15 & $2.3 \mathrm{E}-02$ & $15 \%$ \\
\hline $\mathrm{Cr}_{2} \mathrm{O}_{3}$ & 0.08 & 1E-02 & $12 \%$ \\
\hline $\mathrm{CuO}$ & 0.03 & $1 \mathrm{E}-03$ & $3 \%$ \\
\hline $\mathrm{Fe}_{2} \mathrm{O}_{3}$ & 12.17 & $2.9 \mathrm{E}-01$ & $2.4 \%$ \\
\hline $\mathrm{Gd}_{2} \mathrm{O}_{3}$ & 0.02 & $2 \mathrm{E}-03$ & $8 \%$ \\
\hline $\mathrm{La}_{2} \mathrm{O}_{3}$ & 0.03 & $3 \mathrm{E}-03$ & $11 \%$ \\
\hline $\mathrm{Li}_{2} \mathrm{O}$ & 5.27 & 7.9E-02 & $1.5 \%$ \\
\hline $\mathrm{MgO}$ & 1.16 & $2.3 \mathrm{E}-02$ & $2.0 \%$ \\
\hline $\mathrm{MnO}$ & 1.47 & $3.9 \mathrm{E}-02$ & $2.7 \%$ \\
\hline $\mathrm{MoO}_{3}$ & 0.08 & 7E-03 & $8 \%$ \\
\hline $\mathrm{Na}_{2} \mathrm{O}$ & $11.31^{\mathrm{b}}$ & $2.7 \mathrm{E}-01$ & $2.4 \%$ \\
\hline $\mathrm{NiO}$ & 0.55 & $1.5 \mathrm{E}-02$ & $2.7 \%$ \\
\hline $\mathrm{P}_{2} \mathrm{O}_{5}$ & 0.48 & $2.2 \mathrm{E}-02$ & $4.5 \%$ \\
\hline $\mathrm{PbO}$ & 0.02 & $1 \mathrm{E}-03$ & $5 \%$ \\
\hline $\mathrm{SO}_{4}{ }^{\mathrm{c}}$ & 0.25 & $5.5 \mathrm{E}-03$ & $2.2 \%$ \\
\hline $\mathrm{Sb}_{2} \mathrm{O}_{5}$ & 0.07 & $3 \mathrm{E}-03$ & $5 \%$ \\
\hline $\mathrm{SiO}_{2}$ & $49.31^{\mathrm{a}}$ & $4.5 \mathrm{E}-01$ & $0.91 \%$ \\
\hline $\mathrm{SnO}_{2}$ & 0.25 & $3.5 \mathrm{E}-02$ & $14 \%$ \\
\hline $\mathrm{SrO}$ & 0.29 & $8.2 \mathrm{E}-03$ & $2.8 \%$ \\
\hline $\mathrm{TiO}_{2}$ & 0.06 & 1E-03 & $2 \%$ \\
\hline $\mathrm{U}_{3} \mathrm{O}_{8}$ & 3.36 & $8.7 \mathrm{E}-02$ & $2.6 \%$ \\
\hline $\mathrm{ZnO}$ & 0.05 & 2E-03 & $5 \%$ \\
\hline \multirow[t]{2}{*}{$\mathrm{ZrO}_{2}$} & $0.08^{b}$ & $2 \mathrm{E}-03$ & $2 \%$ \\
\hline & 96.73 & & \\
\hline
\end{tabular}

${ }^{\mathrm{a}}$ Obtained from analysis of peroxide fusion dissolution.

${ }^{\mathrm{b}}$ Obtained from analysis of mixed acid dissolution.

${ }^{\mathrm{c}}$ Obtained from analysis using ADS low sulfur protocol. 
Table 3-3. Concentration of Major (>0.5 Wt. \% Elemental) Components of Glass Pour Stream Sample Taken during Filling of Canister S01913.

\begin{tabular}{||c|c|c|c||}
\hline \hline & $\mathrm{S} 01913$ & $\begin{array}{c}\text { Vitrified SME } \\
\text { Batch 254 }\end{array}$ & $\begin{array}{c}\text { \% Difference } \\
\text { (relative to } \\
\text { SME) }\end{array}$ \\
\hline Oxide & \multicolumn{2}{|c||}{$\mathrm{Wt}^{2} \%$} & -14.3 \\
\hline $\mathrm{Al}_{2} \mathrm{O}_{3}$ & 4.34 & 4.96 & -15.1 \\
\hline $\mathrm{B}_{2} \mathrm{O}_{3}$ & 4.44 & 5.11 & 7.6 \\
\hline $\mathrm{CaO}$ & 1.31 & 1.21 & -8.4 \\
\hline $\mathrm{Fe}_{2} \mathrm{O}_{3}$ & 12.17 & 13.19 & 2.5 \\
\hline $\mathrm{Li}_{2} \mathrm{O}$ & 5.27 & 5.14 & 12.1 \\
\hline $\mathrm{MgO}$ & 1.16 & 1.02 & 5.4 \\
\hline $\mathrm{MnO}$ & 1.47 & 1.39 & 7.0 \\
\hline $\mathrm{Na}_{2} \mathrm{O}$ & 11.31 & 10.52 & 1.4 \\
\hline $\mathrm{SiO}_{2}$ & 49.31 & 48.60 & -11.1 \\
\hline $\mathrm{U}_{3} \mathrm{O}_{8}$ & 3.36 & 3.80 & \\
\hline
\end{tabular}

Table 3-4. Concentrations of Elements in the Dried Sludge Slurry, the Glass Pour Stream Sample, and the Calculated WDF.

\begin{tabular}{||c|c|c|c||}
\hline & \multicolumn{2}{|c||}{ Concentration (Wt \%) } & \\
\hline Element & Dried Sludge Slurry $^{11}$ & Glass & WDF \\
\hline $\mathrm{Al}$ & 5.56 & 2.30 & 2.4 \\
\hline $\mathrm{Ca}$ & 2.19 & 0.94 & 2.3 \\
\hline $\mathrm{Fe}$ & 22.3 & 8.51 & 2.6 \\
\hline $\mathrm{Mn}$ & 2.97 & 1.14 & 2.6 \\
\hline Average (Std. Dev.) & -- & -- & $2.5(0.1)$ \\
\hline
\end{tabular}

\subsection{Radionuclide Composition of the Glass}

Table 3-5 contains the 29 radionuclides in Sludge Batch 2 identified as reportable ${ }^{8}$. Radionuclides in bold are measured using the ICP-MS. Those in italics are measured by counting methods after a separation process. A discussion of the methods is published in Reference 3. The remaining radionuclides in the table are obtained by calculation using a WDF and the measured quantities in the dried sludge slurry ${ }^{8}$.

Table 3-5. Reportable Radionuclides for Macrobatch 3 Identified in Reference 7.

\begin{tabular}{||c|c|c|c|c|c||}
\hline C-14 & Ni-59 & Ni-63 & Se-79 & Sr-90 & Nb-93m \\
\hline Zr-93 & Tc-99 & Sn-121m & Sn-126 & Cs-137 & Sm-151 \\
\hline U-233 & U-234 & U-235 & U-236 & Np-237 & U-238 \\
\hline$P u-238$ & Pu-239 & $P u-240$ & $A m-241$ & $P u-241$ & Pu-242 \\
\hline Am-243 & Cm-244 $^{\dagger}$ & Cm-245 & Cm-246 & Cf-251 & \\
\hline
\end{tabular}

$\dagger \mathrm{Cm}-244$ was not detected by the ICP-MS. Therefore the value reported was calculated from the reported value for $\mathrm{Cm}-244$ in Reference 8. 
Table 3-6 is the radionuclide content of the glass sample determined from either measured values from the glass or calculated from the measured values in Reference 8 . Due to recognized volatility of carbon and iodine in the melter, the waste dilution factors of 60 for C-14 and 24 for I-129 that were used were determined for a previous pour steam sample ${ }^{13}$. The SB2 Qualification samples were washed to a different endpoint than the SB2 sludge processed in DWPF. Thus differences in the values calculated from the sludge analysis and measured from the glass are exacerbated by the washing strategy (insoluble species higher in glass and soluble species lower in glass).

Table 3-6. Radionuclide Content of the Glass Pour Stream Sample Taken during the Filling of Canister S01913.

\begin{tabular}{|c|c|c|c|c|c|c|}
\hline Radionuclides & $\begin{array}{c}\text { Wt \% } \\
\text { Dried } \\
\text { Sludge }^{8}\end{array}$ & $\begin{array}{l}\mathrm{Ci} / \mathrm{Kg}^{8} \\
\text { Sludge }^{8}\end{array}$ & $\begin{array}{l}\text { Wt \% Glass } \\
\text { (Calculated) }\end{array}$ & $\begin{array}{l}\text { Wt \% Glass } \\
\text { (Measured) }\end{array}$ & $\begin{array}{l}\mathrm{Ci} / \mathrm{Kg} \\
\text { Glass }\end{array}$ & Source \\
\hline C-14 & $1.82 \mathrm{E}-07$ & $8.13 \mathrm{E}-06$ & $3.03 \mathrm{E}-09$ & -- & $1.36 \mathrm{E}-07$ & Reference 8 \\
\hline Ni-59 & $3.88 \mathrm{E}-04$ & $3.13 \mathrm{E}-04$ & $1.55 \mathrm{E}-04$ & -- & $1.25 \mathrm{E}-04$ & Reference 8 \\
\hline $\mathrm{Ni}-63$ & $3.97 \mathrm{E}-05$ & $2.05 \mathrm{E}-02$ & $1.59 \mathrm{E}-05$ & -- & $8.20 \mathrm{E}-03$ & Reference 8 \\
\hline Se-79 & $8.95 \mathrm{E}-05$ & $6.23 \mathrm{E}-05$ & $3.58 \mathrm{E}-05$ & -- & $2.49 \mathrm{E}-05$ & Reference 8 \\
\hline Sr-90 & $3.32 \mathrm{E}-03$ & $4.52 \mathrm{E}+00$ & $1.33 \mathrm{E}-03$ & $1.08 \mathrm{E}-03$ & $1.47+00$ & Counting \\
\hline $\mathrm{Nb}-93 \mathrm{~m}$ & $2.6 \mathrm{E}-09$ & $6.30 \mathrm{E}-06$ & $1.04 \mathrm{E}-09$ & -- & $2.52 \mathrm{E}-06$ & Reference 8 \\
\hline $\mathrm{Zr}-93$ & $5.41 \mathrm{E}-03$ & $1.36 \mathrm{E}-04$ & $2.16 \mathrm{E}-03$ & $3.60 \mathrm{E}-04$ & $3.55 \mathrm{E}-04$ & ICP-MS \\
\hline Tc-99 & $7.35 \mathrm{E}-04$ & $1.26 \mathrm{E}-04$ & $2.94 \mathrm{E}-04$ & $2.73 \mathrm{E}-04$ & 4.64E-05 & ICP-MS \\
\hline Sn-121m & $6.77 \mathrm{E}-06$ & $3.64 \mathrm{E}-03$ & $2.71 \mathrm{E}-06$ & -- & $1.46 \mathrm{E}-03$ & Reference 8 \\
\hline Sn-126 & $1.58 \mathrm{E}-04$ & 4.49E-05 & $6.32 \mathrm{E}-05$ & -- & $1.80 \mathrm{E}-05$ & Reference 8 \\
\hline I-129 & $4.29 \mathrm{E}-06$ & $7.57 \mathrm{E}-09$ & $1.78 \mathrm{E}-07$ & -- & $3.15 \mathrm{E}-10$ & Reference 8 \\
\hline Cs-137 & $3.17 \mathrm{E}-04$ & $2.75 \mathrm{E}-01$ & $1.27 \mathrm{E}-04$ & $9.84 \mathrm{E}-05$ & $8.64 \mathrm{E}-02$ & Counting \\
\hline Sm-151 & $6.75 \mathrm{E}-04$ & $1.77 \mathrm{E}-01$ & $2.70 \mathrm{E}-04$ & $2.64 \mathrm{E}-04$ & $6.86 \mathrm{E}-02$ & ICP-MS \\
\hline U-233 & $1.11 \mathrm{E}-04$ & $1.07 \mathrm{E}-05$ & $4.44 \mathrm{E}-05$ & $5.29 \mathrm{E}-05$ & $5.13 \mathrm{E}-06$ & ICP-MS \\
\hline U-234 & $5.72 \mathrm{E}-04$ & $3.57 \mathrm{E}-05$ & 2.29E-04 & $2.63 \mathrm{E}-04$ & $1.63 \mathrm{E}-05$ & ICP-MS \\
\hline U-235 & $3.04 \mathrm{E}-02$ & $6.57 \mathrm{E}-07$ & $1.22 \mathrm{E}-02$ & $1.37 \mathrm{E}-02$ & $3.02 \mathrm{E}-07$ & ICP-MS \\
\hline U-236 & $1.46 \mathrm{E}-03$ & $9.44 \mathrm{E}-07$ & $5.84 \mathrm{E}-04$ & $7.00 \mathrm{E}-04$ & $4.55 \mathrm{E}-07$ & ICP-MS \\
\hline $\mathrm{Np}-237$ & $1.88 \mathrm{E}-03$ & $1.33 \mathrm{E}-05$ & $7.52 \mathrm{E}-04$ & $8.15 \mathrm{E}-04$ & $5.78 \mathrm{E}-06$ & ICP-MS \\
\hline U-238 & $7.53 \mathrm{E}+00$ & $2.53 \mathrm{E}-05$ & $3.01 \mathrm{E}+00$ & $2.87 \mathrm{E}+00^{*}$ & $9.94 \mathrm{E}-06$ & ICP-MS \\
\hline $\mathrm{Pu}-238$ & $2.25 \mathrm{E}-04$ & $3.85 \mathrm{E}-02$ & $9.00 \mathrm{E}-05$ & $7.29 \mathrm{E}-05$ & $1.24 \mathrm{E}-02$ & Counting \\
\hline $\mathrm{Pu}-239$ & $1.24 \mathrm{E}-02$ & $7.68 \mathrm{E}-03$ & $4.96 \mathrm{E}-03$ & $6.46 \mathrm{E}-03$ & $4.00 \mathrm{E}-03$ & ICP-MS \\
\hline $\mathrm{Pu}-240$ & $1.05 \mathrm{E}-03$ & $2.38 \mathrm{E}-03$ & $4.20 \mathrm{E}-04$ & $5.59 \mathrm{E}-04$ & $1.28 \mathrm{E}-03$ & ICP-MS \\
\hline $\mathrm{Pu}-241$ & $2.71 E-05$ & $2.80 \mathrm{E}-02$ & $1.08 \mathrm{E}-05$ & $8.48 \mathrm{E}-06$ & $8.48 \mathrm{E}-03$ & Counting \\
\hline Am-241 & $9.53 \mathrm{E}-04$ & $3.27 \mathrm{E}-02$ & $3.81 \mathrm{E}-04$ & $2.99 \mathrm{E}-04$ & $1.03 \mathrm{E}-02$ & Counting \\
\hline $\mathrm{Pu}-242$ & $1.16 \mathrm{E}-04$ & $4.59 \mathrm{E}-06$ & $4.64 \mathrm{E}-05$ & $7.88 \mathrm{E}-05$ & $3.07 \mathrm{E}-06$ & ICP-MS \\
\hline Am-243 & $2.68 \mathrm{E}-04$ & $5.34 \mathrm{E}-04$ & $1.07 \mathrm{E}-04$ & $9.62 \mathrm{E}-05$ & $1.92 \mathrm{E}-04$ & ICP-MS \\
\hline $\mathrm{Cm}-244$ & $5.48 \mathrm{E}-05$ & $4.42 \mathrm{E}-02$ & $2.19 \mathrm{E}-05$ & $--^{\dagger}$ & $1.77 \mathrm{E}-02$ & Reference 8 \\
\hline $\mathrm{Cm}-245$ & $2.25 \mathrm{E}-06$ & $3.86 \mathrm{E}-06$ & $9.00 \mathrm{E}-07$ & -- & $1.54 \mathrm{E}-06$ & Reference 8 \\
\hline $\mathrm{Cm}-246$ & $8.06 \mathrm{E}-06$ & $2.48 \mathrm{E}-05$ & $3.22 \mathrm{E}-06$ & -- & $9.92 \mathrm{E}-06$ & Reference 8 \\
\hline Cf-251 & $7.52 \mathrm{E}-07$ & $1.19 \mathrm{E}-05$ & $3.01 \mathrm{E}-07$ & -- & $4.76 \mathrm{E}-06$ & Reference 8 \\
\hline
\end{tabular}

*For comparison, the total uranium measured from ICP-AES was $2.85 \mathrm{E}+00 \mathrm{wt} \%$.

${ }^{\dagger} \mathrm{Cm}-244$ was not detected in the ICP-MS sample. Therefore, the value was calculated using the values in Reference 8. 


\subsection{Noble Metal Composition of the Glass}

The concentration of the noble metals of interest; silver $(\mathrm{Ag})$, palladium $(\mathrm{Pd})$, rhodium $(\mathrm{Rh})$, and ruthenium $(\mathrm{Ru})$ were calculated based on ICP-MS results of one or more isotopes. The total ruthenium in the sludge consists of the three nonradioactive isotopes, Ru-101, Ru-102, and $\mathrm{Ru}-104$. Thus the total ruthenium concentration is the sum of the concentrations of these three isotopes. The single isotope for rhodium is Rh-103. The total palladium is comprised of five isotopes. These are Pd-105, Pd-106, Pd-107, Pd-108, and Pd-110. Because natural silver and cadmium share the same mass as several of the palladium isotopes, and both may exist in the sludge, only one palladium isotope, Pd-105, could be measured in the glass. The concentrations of the remaining isotopes of palladium were calculated by multiplying the measured concentration of Pd-105 by the ratio of the fission yield for that specific isotope relative to the fission yield for Pd-105. The total palladium is then the sum of these five concentrations. The total silver is comprised of isotopes Ag-107 and Ag-109. Table 3-7 is the concentration of these noble metals in the glass sample along with the concentrations from Reference 11 and the calculated concentrations using the WDF from Table 3-4.

Table 3-7. Measured Noble Metal Concentration in Glass Pour Stream Sample Taken during the Filling of Canister S01913.

\begin{tabular}{||c|c|c|c||}
\hline \hline Noble Metal & $\begin{array}{c}\text { Wt \% Dried } \\
\text { Sludge }^{11}\end{array}$ & $\begin{array}{c}\text { Wt \% Glass } \\
\text { (Calculated) }\end{array}$ & $\begin{array}{c}\text { Wt \% Glass } \\
\text { (Measured) }\end{array}$ \\
\hline $\mathrm{Ag}$ & $1.06 \mathrm{E}-02$ & $4.24 \mathrm{E}-03$ & $3.10 \mathrm{E}-03$ \\
\hline $\mathrm{Pd}$ & $8.85 \mathrm{E}-04$ & $3.54 \mathrm{E}-04$ & $3.24 \mathrm{E}-04$ \\
\hline $\mathrm{Rh}$ & $7.77 \mathrm{E}-03$ & $3.11 \mathrm{E}-03$ & $2.17 \mathrm{E}-03$ \\
\hline $\mathrm{Ru}$ & $3.32 \mathrm{E}-02$ & $1.33 \mathrm{E}-02$ & $1.29 \mathrm{E}-03$ \\
\hline
\end{tabular}

\subsection{Product Consistency Test}

The analyses of the ARM-1 glass, standard solutions and blanks met the requirements for experimental control as specified in Reference 9. Results are located in laboratory notebook, "DWPF Glass Pour Stream Samples Sludge Batch 2", WSRC-NB-2002-00092.

The concentrations of several elements in the leachate were measured using ICP-AES. The concentrations were used along with the chemical composition of the glass (measured values for the glass sample and published $^{14}$ values for the ARM-1 and EA glasses) to calculate the average normalized releases in terms of grams of glass dissolved per liter of leachate based on specific elements in the glass. Results are presented for boron, sodium, lithium, and silicon in Table 3-8 as the average normalized releases and measured leachate $\mathrm{pH}$ of the sample along with predicted values using the PCT/chemical composition correlations from THERMO ${ }^{14}$. The average measured values for the EA glass are also presented along with published values ${ }^{15}$. Silicon is not required by the Waste Acceptance Product Specifications (WAPS $)^{16}$ but is provided because it is a major component of the glass. The leachate $\mathrm{pH}$ was measured as part of the PCT protocol and provides a secondary indication of glass durability.

The normalized elemental release ranges reported in Table 3-8 indicate that the glass sample taken during the filling of canister S01913 met the acceptance criterion as defined in the WAPS. This criterion states that the normalized boron release glass produced must be at least two standard deviations* better than the EA glass15. The boron release for the glass is seven standard deviations better than the EA glass. The measured release for boron from the EA glass in this test was lower than the published values. However,

\footnotetext{
${ }^{*}$ Standard deviation of the mean (1.222) from Reference 15 adjusted for quadruplicate samples (1.045).
} 
the results of the standard ARM glass indicate the PCT was valid. The exact reason for the results for the PCT response of the EA being low is not known, but this has been observed in previous PCT tests with radioactive DWPF glass ${ }^{17,18,19,20}$

Table 3-8. Normalized PCT Results (Measured and Predicted) for Glass Pour Stream Sample Taken during the Filling of Canister S01913.

\begin{tabular}{||c|c|c|c|c||}
\hline Element & $\begin{array}{c}\text { Measured } \\
(\mathrm{g} / \mathrm{L}, \text { Std. Dev., \%RSD })\end{array}$ & $\begin{array}{c}\text { Predicted } \\
(\mathrm{g} / \mathrm{L})\end{array}$ & $\begin{array}{c}\text { Measured } \\
\text { EA } \\
(\mathrm{g} / \mathrm{L} ., \text { Std. Dev. })\end{array}$ & $\begin{array}{c}\text { Published }^{15} \\
\text { EA g/L., Std. Dev. })\end{array}$ \\
\hline $\mathrm{B}$ & $1.18,0.03,2.4$ & 1.13 & $10.5,1.2$ & $16.7,1.2$ \\
\hline $\mathrm{Na}$ & $1.11,0.03,2.3$ & 1.10 & $8.5,0.9$ & $13.3,0.9$ \\
\hline $\mathrm{Li}$ & $1.10,0.03,2.4$ & 1.09 & $7.9,0.7$ & $9.6,0.7$ \\
\hline $\mathrm{Si}$ & $0.73,0.02,2.3$ & N/A & 3.0 & 3.9 \\
\hline $\mathrm{pH}$ & 10.4 & N/A & 11.4 & 11.9 \\
\hline \hline
\end{tabular}

\subsection{Density}

Crushed samples were used to measure the density of the glass sample taken during the filling of canister S01913. The measurement was performed in triplicate. The limited mass of sample available dictated the use of a small volumetric flask to achieve satisfactory resolution. The standard glass typically measured is a monolith, too large to be measured in the equipment used for this sample. Table 3-9 is the results along with the density calculated from the major components of the glass ${ }^{21}$. A molar volume factor for uranium was not provided in the literature. An estimate was used based on the molar volume of $\mathrm{U}_{3} \mathrm{O}_{8}$ and the factor used to modify molar volumes for other large cations.

Table 3-9. Density of the Glass Pour Stream Sample Taken during the Filling of Canister S01913.

\begin{tabular}{||c|c|c|c|c||}
\hline & Replicates & $\begin{array}{c}\text { Density @ } 23^{\circ} \mathrm{C} \\
\left(\mathrm{g} / \mathrm{cm}^{3}\right)\end{array}$ & $\begin{array}{c}\text { Standard } \\
\text { Deviation }\end{array}$ & $\begin{array}{c}\text { Relative Standard } \\
\text { Deviation }\end{array}$ \\
\hline canister S01913 & 3 & 2.56 & 0.03 & $1.2 \%$ \\
\hline Calculated & -- & 2.52 & -- & -- \\
\hline
\end{tabular}




\subsection{CONCLUSIONS}

- The glass sample taken during the filling of canister S01913 received at SRNL weighed 33.04 grams and was dark and reflective with no obvious inclusions indicating the glass was homogeneous.

- The results of the composition for glass sample S01913 are in good agreement with the DWPF SME results for Batch Number 254, the SME Batch that was being fed to the melter when the sample was collected.

- The calculated waste dilution factor (WDF) was 2.5. The measured values of radionuclides and noble metals in the glass sample corresponded well with the calculated values determined using sludge slurry results from Reference 8 and the WDF.

- The noble metal content of the glass indicates that the noble metals are not retained in the melter.

- The PCT results for the glass (normalized boron release of $1.18 \mathrm{~g} / \mathrm{L}$ ) indicate that it is greater than seven standard deviations more durable than the EA glass; thus, the glass meets the waste acceptance criterion for durability.

- The measured density of the glass was $2.56 \pm 0.03 \mathrm{~g} / \mathrm{cm}^{3}$. 
WSRC-TR-2004-00316

Revision 1

This page intentionally left blank. 


\subsection{REFERENCES}

${ }^{1}$ Ray, J. W., Staub, A. V., Plodinec, M. J. and Marra, S.L., DWPF Glass Product Control Program (U). WSRC-IM-91-116-6, Rev. 4, Savannah River Site, Aiken, SC 29808 (2003).

2 Staub, A.V., Analysis of Macro-Batch 3 DWPF Pour Stream Glass Sample(s). Technical Task Request, HLW/DWPF/TTR-02-0015, Rev. 0, Savannah River Site, Aiken, SC 29808 (2002).

${ }^{3}$ Cozzi, A.D., Analysis of Macrobatch 3 Pour Stream Glass Sample: Task Technical \& QA Plan WSRCRP-2004-00042, Rev. 0, Savannah River Site, Aiken, SC 29808 (2004).

${ }^{4}$ Cozzi, A.D., Analysis of Macrobatch 3 Pour Stream Glass Sample: Analytical Study Plan WSRC-RP2004-00043, Rev. 0, Savannah River Site, Aiken, SC 29808 (2004).

${ }^{5}$ L16.1 ADS Procedure Manual ADS-2227 Acid Dissolution of Glass and Sludge for Elemental Analysis.

${ }^{6}$ L16.1 ADS-2502, Sodium Peroxide/Sodium Hydroxide Dissolutions of Sludge and Glass for Elemental and Anion Analysis.

7 Smith, G.L., Characterization of Analytical Reference Glass 1 (ARG-1), Pacific Northwest National Laboratory Report, PNNL-8992, 1993.

${ }^{8}$ Bibler, N.E., DiPrete, D.P., and Harbour, J.R., Determination of Reportable Radionuclides for DWPF Sludge Batch 2 (Macro Batch 3) (U), WSRC-TR-2002-00255, Rev.1 (2002).

9 Jantzen, C.M., Bibler, N.E., Beam, D.C., Ramsey, W.G., and Waters, B.J., Nuclear Waste Glass Product Consistency Test (PCT) -Version 7.0 (U), WSRC-TR-90-539, Rev.3, (1994).

${ }^{10}$ ASTM D 854 Standard Test Methods for Specific Gravity of Soil Solids by Water Pycnometer.

${ }^{11}$ Fellinger, T.L., Pareizs, J.M., Bibler, N.E., Cozzi, A.D., and Crawford, C.L., Confirmation Run of the DWPF SRAT Cycle Using the Sludge-Only Flowsheet with Tank 40 Radioactive Sludge and Frit 200 in the Shielded Cells Facility (U), WSRC-TR-2002-00076, (2002).

${ }^{12}$ Staub, A.V., Ray, J.W., Edwards, T.B., Bibler, N.E., and Marra, S.L., Reporting the Radionuclide Inventory of the DWPF Product (U), WSRC-IM-91-116-4, Rev. 2, (2003).

${ }^{13}$ Bibler, N.E. and Fellinger, T.L., Results of the Radionuclide Composition for the DWPF Macro Batch 2 Glass Pour Stream Sample Taken During the Pouring of Canister S01142 (U),WSRC-RP-2000-00418, Rev. 1, (2004).

${ }^{14}$ Jantzen, C.M., Pickett, J.B., Brown, K.G., Edwards, T.B., and Beam, D.C., Process/Product Models for the Defense Waste Processing Facility (DWPF): Part I. Predicting Glass Durability From Composition Using Thermodynamic Hydration Energy Reaction Model (THERMO) (U), WSRC-TR-93-672, Rev.1, (1995).

${ }^{15}$ Jantzen, C.M., Bibler, N.E., Beam, D.C., Crawford, C.L., and Pickett, M.A., Characterization of the Defense Waste Processing Facility (DWPF) Environmental Assessment (EA) Glass Standard Reference Material (U), WSRC-TR-92-346, Rev. 1, (1994). 
${ }^{16}$ Office of Environmental Restoration and Waste Management, Waste Acceptance Product Specifications for Vitrified High-Level Waste Forms, USDOE Document DOE/EM-0093, Rev. 2, (1996).

${ }^{17}$ Fellinger, T.L. and. Bibler, N.E, "DWPF Glass Results for the Analysis of a Pour Stream Sample Taken During the Pouring of the 409th Canister (Canister S00834) in Macrobatch 1 (U)", WSRC-RP-9801400, Rev. 0, (1999).

${ }^{18}$ Hodoh, O.B., Fellinger, T.L., and Bibler, N.E., "DWPF Glass Results For the Analysis of a Pour Stream Sample Taken During Pouring of the 50th Canister (Canister S00471) (U)", WSRC-RP-9800053, Rev. 0, (1998).

${ }^{19}$ Hodoh, O.B., Fellinger, T.L., and Bibler, N.E., "DWPF Glass Results For the Analysis of a Pour Stream Sample Taken During Pouring of the 61st Canister (Canister S00482) (U)", WSRC-RP-9800054, Rev. 0, (1998).

${ }^{20}$ Fellinger, T.L. and. Bibler, N.E, "Results of the Chemical Composition and the Product Consistency Test for the DWPF Macro Batch 2 Glass Pour Stream Sample Taken During the Pouring of Canister S01142 ) (U)", WSRC-RP-299-00281, Rev.0, (2000).

${ }^{21}$ Varshneya, A.K., Fundamentals of Inorganic Glasses, Academic Press, Inc. San Diego, CA (1994). 
WSRC-TR-2004-00316

Revision 1

This page intentionally left blank. 